\title{
Kajian Sastra Bandingan Pada Lirik Lagu Demi Kowe Karya Pendhoza dan Merantau Karya Abah Lala
}

\author{
Ferdian Achsani \\ Tadris Bahasa Indonesia, Fakultas Adab dan Bahasa \\ Institut Agama Islam Negeri Surakarta \\ dwikurniawan219@gmail.com
}

\begin{abstract}
This study aims to reveal the similarities and differences in Pendhoza's Demi Kowe song lyrics with the song lyrics Merantau by Abah Lala. This research is included in the type of qualitative descriptive research with a comparative literary approach. The data collection technique used is the technique of reading and recording. The researcher reads the two song lyrics and records the similarities and differences between the two song lyrics. Data analysis techniques use interactive techniques that include data reduction processes, data display and conclusion drawing. The results showed that the two songs had similarities and differences. The similarity between the two songs lies in the character values, please help, discipline, responsibility, and independence. The difference between the two songs can be seen in terms of the story that Demi Kowe's song lyrics tell more about the return of a man after going overseas to keep his promises. In Demi Kowe's song lyrics, religious values were also found that were not found in Merantau's song lyrics. In the song lyrics of Merantau the difference lies in the content of the story that tells about the struggle of a husband who lives in the land of rantau. In addition, in the song lyrics Merantau also tells about the suspicions and emotions of a husband towards the wife who was left at home.
\end{abstract}

Keywords: song lyrics, comparative literature, male struggle.

Abstrak: Penelitian ini bertujuan untuk mengungkapkan persamaan dan perbedaan dalam lirik lagu Demi Kowe karya Pendhoza dengan lirik lagu Merantau karya Abah Lala. Penelitian ini termasuk dalam jenis penelitian deskriptif kualitatif dengan pendekatan sastra bandingan. Teknik pengumpulan data yang digunakan yaitu teknik baca dan catat. Peneliti membaca kedua lirik lagu dan mencatat persamaan dan perbedaan di antara kedua lirik lagu tersebut. Teknik analisis data menggunakan teknik interaktif yang meliputi proses reduksi data, display data dan penarikan kesimpulan. Hasil penelitian menunjukkan bahwa kedua lagu tersebut memiliki kesamaan dan perbedaan. Kesamaan antara kedua lagu tersebut yaitu terletak pada nilai-nilai karakter tolong menolong, disiplin, tanggung jawab, dan mandiri. Perbedaan dari kedua lagu tersebut dapat dilihat dari segi cerita bahwa lirik lagu Demi Kowe lebih menceritakan tentang kepulangan seorang laki-laki setelah pergi Merantau untuk menepati janjinya. Dalam lirik lagu Demi Kowe juga ditemukan nilai religius yang tidak ditemukan pada lirik lagu Merantau. Pada lirik lagu Merantau perbedaan

ESTETIK : Jurnal Bahasa Indonesia, vol. 2, no. 1, 2019

IAIN Curup - Indonesia | ISSN 2622-1810 (p); 2622-1829 (e)

DOI: $10.29240 /$ estetik.v2i01.817 
terletak pada isi cerita yang menceritakan tentang perjuangan suami yang hidup di tanah rantau. Selain itu dalam lirik lagu Merantau juga menceritakan tentang kecurigaan dan emosi seorang suami terhadap istri yang ditinggal di rumah.

Kata kunci: lirik lagu, sastra bandingan, perjuangan laki-laki.

\section{PENDAHULUAN}

Musik dangdut mungkin sudah tidak asing lagi didengar oleh masyarakat Indonesia. Dangdut sebagai identitas bangsa Indonesia yang jauh muncul sebelum era kemerdekaan NKRI ini (Inderasari \& Achsani, 2018:326), kini semakin populer dan semakin digemari oleh masyarakat. Musik dangdut yang semula dianggap ndeso, kampungan dan norak kini seakan menjadi genre musik yang digemari oleh masyarakat dari lapisan bawah, menengah hingga lapisan atas. Hal ini dikarenakan selain alunan perpaduan musik yang dapat menghibur suasana hati juga tidak luput dari peran lirik lagu yang mewakili perasaan pendengar. Dengan bahasa yang sederhana dan merakyat membuat music dangdut semakin dinanti-nanti oleh masyarakat pecinta music dangdut. Suka Harjana (dalam Kholis, 2018) mengatakan bahwa musik dangdut berasal dari musik Melayu yang telah bersinggungan dengan musik India, Islam timur tengah. Perkembangan music dangdut kinipun mulai beragam dari yang semula dangdut melayu klasik, koplo atau pantura hingga sekarang dangdut dibuat dengan versi hiphop.

Genre music dangdut hiphop merupakan salah satu genre music dangdut yang paling baru. Hadirnya music dangdut bergenre hiphop ini mampu merebut hati para remaja untuk mencintai music dangdut. Perkembangan music dangdut hiphop semakin marak pada tahun 2018 lalu ketika public sempat dibuat heboh dengan kemunculan Pendhoza, duo pedangdut hiphop yang membawakan lagu berjudul Bojo Galak. Sejak kemunculannya yang memberi warna baru di dunia music dangdut, kini Pendhoza kembali membawakan single terbaru mereka berjudul Demi Kowe yang berhasil meraih viewers 5.9 JT dari netizen di jejaring sosial YouTube. Kepopuleran lagu tersebut tidak luput dari isi lagu yang menceritakan tentang fenomena masyarakat, yaitu tentang perjuangan seorang laki-laki yang pergi merantau demi untuk mengumpulkan uang agar bisa menikahi kekasihnya. Hal tersebut merupakan gambaran masyarakat saat ini tentang perjuangan seorang laki-laki demi mewujudkan cita-citanya untuk bisa bersanding dengan 
kekasihnya, sehingga menjadikan lagu ini dikenal dan diterima baik oleh masyarakat.

Selain duo pedangdut hiphop Pendhoza, masyarakat penggemar music dangdut juga sempat digegerkan dengan kedatangan orkes musik Abah Lala yang sukses meng-cover lagu Pamer Bojo. Lagu yang diciptakan sekaligus dipopulerkan oleh Didi Kempot ini seakan menjadi lagu Abah Lala ketika dinyanyikan dengan garapan musik rancak (gedruk) dan suara dari penyanyinya yang khas. Berkat cover lagu tersebut, Abah Lala semakin dikenal oleh masyarakat dan mulai menciptakan beberapa lagu, misalnya saja berjudul Merantau. Sama dengan lagu Demi Kowe, lagu Merantau karya Abah Lala ini juga menceritakan fenomena masyarakat tentang perjuangan seorang lakilaki yang pergi merantau demi untuk membahagiakan istri tercintanya.

Kedua lirik tersebut merupakan bentuk cerminan kehidupan manusia yang sesuai dengan hakikat karya sastra. Hal ini dikarenakan permasalahan yang menjadi topik dalam isi lagu tersebut merupakan fenomena yang terjadi di masyarakat saat ini. Kehadiran kedua karya tersebut tidak terlepas dari lingkungan kehidupan si pengarang. Melalui lirik tersebut pengarang ingin berkomunikasi kepada pendengar melalui isi dan pesan dalam lirik lagu tersebut (Sugihastuti, 2011: 25). Baik lirik Demi Kowe maupun lirik Merantau keduanya berusaha untuk menampilkan keadaan masyarakat yang berjuang di tanah rantau demi untuk mewujudkan impiannya, yaitu membahagiakan orang-orang terkasihnya. Hal itu sesuai yang disampaikan oleh Ratna (2013) bahwa karya sastra berusaha untuk menjelaskan gejala sosial pada suatu masyarakat tertentu. Dalam lirik lagu ini pengarang ingin menjelaskan gejala sosial tentang kerasnya hidup atau tentang perjuangan kehidupan yang dialami oleh pengarang di tanah rantau.

Jika dilihat lebih dekat kedua lagu ini hampir memiliki kesamaan tema. Sebagaimana yang kita ketahui bahwa tema merupakan maksud yang ingin ditonjolkan dalam sebuah cerita (Waluyo, 2011), maka kedua lirik lagu tersebut dapat dikatakan memiliki tema yang sama. Sebagai bagian dari karya sastra, kesamaan tema dari kedua lagu tersebut bukanlah suatu bentuk plagiasi. Suatu karya sastra hadir karena adanya karya yang hadir sebelumnya sebagai dasar untuk penciptaan karya sastra yang baru. Dari karya sastra sebelumnya, pengarang melengkapinya ke dalam cerita yang dibuat baru. Ratna (2013:177) menyatakan bahwa kehadiran suatu teks tidak ada yang benar-benar asli, tanpa dipengaruhi kehadiran teks-teks yang lain. Pengarang akan mengambil komponen-komponen dari karya sastra yang sudah ada 
tersebut, kemudian ketika menyusun suatu lirik pengarang akan memasukkannya ke dalam lirik yang ia tulis. Dengan diberi balutan warna yang lebih menarik maka akan menjadikan suatu karya terlihat utuh yang berbeda dengan karya yang sudah ada sebelumnya.

Dari kedua lirik tersebut sehingga dalam penelitian ini akan dilakukan kajian sastra bandingan. Setiap karya sastra pasti memiliki persamaan dan perbedaan tersendiri. Adanya persamaan dan perbedaan tersebutlah yang memunculkan kajian sastra badian untuk menyelisiknya. Ni'mah (2017:95) mendefinisikan sastra bandingan sebagai studi karya yang membandingkan antara satu karya sastra dengan karya sastra yang lain atau dengan ilmu bidang lainnya. Artinya suatu karya sastra misalnya puisi dapat dibandingkan dengan karya puisi yang lain, atau karya sastra yang lain seperti novel ataupun cerpen, ataupun yang lainnya seperti agama, politik, filsat, dan lain-lain. Studi sastra bandingan tidak harus berfokus seperti aliran Amerika dan Prancis yang menyatakan bahwa studi bandingan karya sastra hanya dapat dilakukan lintas negara ataupun antar bahasa (Rokhmansyah, 2014: 171). Kedua aliran tersebut sependapat bahwa sastra bandingan harus dilakukan dengan membandingkan karya sastra yang keduanya berbeda negara.

Namun aliran mahzab tersebut berbeda dengan pendapat Damono (2005) yang menyatakan bahwa sastra bandingan dapat digunakan untuk membandingkan karya sastra sesama bangsa, bahasa, tema dan antar pengarang. Sehingga suatu karya sastra yang berasal dari daerah, bahasa, atau bahkan pengarang yang sama dapat dikaji menggunakan kajian sastra bandingan. Sastra bandingan merupakan studi sastra yang tidak hanya membandingkan bentuk struktur pada karya sastra. Sastra bandingan lebih luas cakupannya karena mengkaji persamaan dan perbedaan dari kedua karya sastra yang dibandingkan. Peneliti dalam menerapkan studi sastra bandingan harus mampu menemukan kekhasan dari masing-masing karya sastra yang dibandingkan. Dalam melakukan pengkajian terhadap karya sastra dengan menggunakan sastra bandingan, peneliti harus membaca karya sastra yang akan dibandingkan, kemudian merumuskannya ke dalam kategori pengelompokkan.

Penelitian terkait sastra bandingan pernah dilakukan oleh Maghfiroh (2018) yang membandingkan Citra Perempuan Jawa dalam Novel CantingKarya Arswendo Atmowiloto dan Amba Karya Laksmi Pamuntjak. Melalui pendekatan sastra bandingan, Maghfiroh menyimpulkan bahwa erikut. Pertama, Citra diri perempuan Jawa 
terbagi menjadi dua aspek, yaitu aspek fisik dan psikis. Kedua, terdapat tiga aspek yang dibandingkan dalam kaitannya dengan peran perempuan Jawa dalam keluarga antara novel Canting dan Amba, yaitu aspek pengambilan keputusan dalam keluarga, aspek ekonomi, dan aspek seksualitas. Ketiga, baik novel Canting maupun Amba, masih terdapat stereotip negatif bahwa perempuan masih menjadi makhluk nomor dua ketika berada di sektor publik dan tidak diberi hak mengenyam pendidikan yang sama dengan laki-laki. Persamaan penelitian ini dengan penelitian tersebut adalah kajian yang digunakan, yaitu menggunakan sastra bandingan. Perbedaan dari penelitian ini adalah objek yang diteliti. Penelitian yang dilakukan oleh Maghfiroh mengkaji tentang citra perempuan dalam karya sastra novel, sedangkan pada penelitian ini mengkaji tentang perbandingan pada karya sastra lirik lagu.

Penelitian yang dilakukan oleh Ni'mah (2017) tentang pandangan nasionalisme pada puisi Maḥmūd Darwisy yang berjudul Bitāqah Hāwiyyah Dan puisi Rendra yang berjudul Gugur melalui kajian sastra banding. Hasil penelitian ini menunjukkan bahwa meskipun kedua puisi tersebut memiliki perspektif yang berbeda dalam memandang suatu negara, akan tetapi, kedua puisi tersebut memiliki wujud rasa nasionalisme yang sama, yaitu sebuah perjuangan melawan penjahahan. Pada puisi Darwisy, mengibaratkan bahwa negara Palestina sebagai sebuah rumah tempat berlindung bagi warga palestina. Maka ketika datang pihak lain yang datang dan ingin merebut Negara Palestina, rakyat pun berjuang keras untuk mempertahankannya. Pada puisi Rendra, Negara diibaratkan sebagai bagian dari jiwa raganya dan tidak dapat dipisahkan dengan kehidupan manusia. Persamaan penelitian ini dengan penelitian yang akan dilakukan adalah dari segi pendekatan sastra bandingan yang akan dilakukan. Sedangkan perbedaan dengan penelitian tersebut adalah terletak pada objek yang akan diteliti. Jika dalam penelitian Ni'mah menggunakan puisi sebagai objek penelitian, dalam penelitian ini menggunkan lirik lagu sebagai objek penelitian.

\section{METODE PENELITIAN}

Penelitian ini termasuk dalam jenis penelitian deskriptif kualitatif. Menurut Muhammad (2014) metode kualitatif merupakan metode yang menafsirkan dan menyajikan data analisis dalam bentuk deskripsi. Santosa (2017: 63) menyatakan bahwa dalam penelitian kualitatif peneliti akan menyimak, memahami, menata, mengklasifikasikan, menghubungkan antar kategori, dan 
menginterpretasikan data berdasarkan konteksnya. Pemilihan metode deskriptif sebagai metode dalam penelitian ini dikarenakan data yang digunakan sebagai objek penelitian berbentuk teks ataupun dokumen tertulis. Dalam penelitian ini peneliti ingin membandingkan perjuangan laki-laki dalam membahagiakan orang yang dicintainya, serta persamaan dan perbedaan dalam lirik lagu Demi Kowe karya Pendhoza dengan lirik lagu Merantau karya Abah Lala. Sehingga dalam penelitian ini menggunakan sastra bandingan sebagai pendekatan dalam penelitian ini. Pengumpulan data dilakukan dengan membaca dan mencatat isi dari kedua lagu tersebut yang memiliki kesamaan dan perbedaan. Analisis data dilakukan dengan cara mengikuti alur miles dan huberman yaitu: 1 . Mengidentifikasi lirik lagu Demi Kowe dan Merantau sebagai objek atau data penelitian, 2. Mereduksi data yang telah dikumpulkan, 3. Menyajikan data penelitian yang telah direduksi, 4. Menarik kesimpulan.

\section{HASIL DAN PEMBAHASAN}

\section{Analisis Isi Lirik Lagu}

Laki-laki diciptakan dengan beberapa kelebihan yang tidak dimiliki oleh perempuan. Kekuatan dalam dirinya mampu membuatnya menjadi seorang yang mandiri apabila ia mampu mengoptimalkannya. Malu bagi seorang laki-laki apabila ia hanya mengandalkan orang lain tanpa ada usaha dalam dirinya dalam menggapai segala keinginannya. Bukan hanya sekedar omong kosong atau bermulut besar yang hanya diandalkan, namun bagi seorang laki-laki bukti atau tindakan yang pasti adalah hal yang utama yang harus dilakukan agar membuat perempuan yang dicintai akan mempercayainya. Dalam menjalankan setiap tindakan yang dilakukannya seorang laki-laki membutuhkan pengorbanan besar, agar mampu membuat perempuan yang dicintainya yakin dan percaya.

Dik aku bali, arep nepati janji

Tak jaluk kowe ra ngapusi

Lungaku wingi amung golek rejeki

Tak bukteke kowe ojo mbedo ati

Uwes seprene suwene aku lunga ninggal kowe

Adoh paran yo mung dinggo kowe

Dalam lirik di atas menceritakan bagaimana bentuk kesetiaan dan pengorbanan yang dilakukan oleh seorang laki-laki kepada kekasihnya. Kepulangan seorang laki-laki setelah pergi jauh meninggalkan kekasihnya, kini ia kembali pulang untuk menepati 
janjinya sekaligus menagih janjinya. Dalam lirik tersebut berisi bahwa sang lelaki pergi jauh demi mencari rezeki agar ia bisa menepati janjinya. Hal tersebut merupakan salah satu bukti betapa tulusnya rasa cinta yang diberikan seorang laki-laki kepada kekasihnya. Perjuangan bagi seorang laki-laki dalam mempertahankan rasa cinta yang ia miliki kepada seseorang yang dicintainya membutuhkan pertaruhan yang besar. Salah satunya yaitu ia rela berpisah jauh dan sekian lamanya tidak pernah bertemu dengan kekasihnya, tidak menyurutkan rasa cinta yang dimilikinya. Bagi laki-laki sejati kesetiaan adalah harga mahal yang harus dimiliki.

Aku lilo adoh omah, adoh wong tuwo

Demi kowe ben supaya tetep mulya

Tresnaku ra bakal ilang senajan adoh paranku

Setiaku karo kowe tekan matiku

Merantau mungkin menjadi salah satu bentuk pengorbanan yang sering dilakukan oleh laki-laki. Dengan merantu pergi dari desa ke kota seorang laki-laki berharap agar bisa mendapatkan penghasilan dan kehidupan yang mapan atau layak, sehingga mampu mencukupi kebutuhan pribadi, keluarga dan orang yang dicintainya. Jauh dari keluarga, dari orang-orang yang disayang merupakan salah satu resiko yang harus ditanggung bagi seorang laki-laki yang pergi merantau demi menggapai cita-cita yang diharapkannya. Hal tersebut merupakan bentuk pengorbanan yang paling berat dirasakan bagi orang-orang yang berjuang demi cita-cita. Ketika mereka diperanturauan mereka seakan hidup mandiri tanpa campur tangan dari orang-orang yang biasa membantunya. Bahkan terkadang rasa rindu terhadap orang tua, terutama ibu, menjadi penyakit yang tidak ada obatnya.

Dalam masalah hubungan, salah satu gondaan yang paling berat ketika ditinggal merantau adalah mereka harus menjalin hubungan jarak jauh. Ketika mereka tak mampu menjaga kepercayaan, maka rasa curiga akan menghantui dalam hubungan yang dijalani. Maka dalam hal ini ujian dalam sebuah hubungan tengah terjadi. Bagi orang-orang yang menjalani hubungan jarak jauh sebagian besar ada yang berhasil, namun sebagian besar ada pula yang gagal. Semua itu tergantung pada komitmen dan kesetiaan dari masing-masing pasangan. Dalam lirik di atas diceritakan bahwa tresno (cinta), rasa sayang dari sang laki-lski kepada kekasihnya tidak akan pernah berubah meskipun jarak menjadi penghalangnya. Hal ini menjadi komitmen dari sang lelaki terhadap pacarnya bahwa ia mencintai kekasihnya meskipun jarak menjadi penghalang untuk bertemu dan mengungkapkan rindu. 
Aku lunga ra ngilang, nanging mergo kahanan

Aku ora ngapusi, bakal tak perjuangkan

Mikir masa depan karo golek modal

Dingo sesuk rabi, duduk di pelaminan

$\mathrm{Ra}$ de det ra de yang (tidak punya uang, tidak punya pacar). Jargon yang berkembang di masyarakat Jawa ini seolah menjadi penyemangat bagi para laki-laki untuk lebih giat lagi dalam bekerja dan mengumpulkan uang. Fenomena yang berkembang saat ini di mana perempuan tidak ingin memiliki pasangan kere, miskin atau tidak memiliki uang menjadi penghalag bagi laki-laki miskin untuk mendekati perempuan yang cantik. Perempuan akan lebih memilih menikah dengan laki-laki yang mempunyai motor FU atau motor ninja bahkan setang bunder (mobil). Penggambaran symbol motor FU atau motor ninja bahkan setang bunder (mobil) identic dengan orang-orang kaya, sehingga perempuan mana yang tidak mudah tertarik dengan mereka. Ketika perempuan dilirik oleh lelaki yang memiliki kendaran-kendaran berharga tinggi tersebut, mereka gampang tergoda dan memilih untuk selingkuh tidak mementingkan wajah tampan atau jelek.

Fenomena masyarakat yang demikian menjadikan laki-laki ingin berjuang mengumpulkan uang agar ia dapat memiliki perempuan yang dicintainya. Adanya fenomena tersebut menjadikan merantau menjadi salah satu jalan yang dilakukan demi memenuhi kepuasan batin agar keinginannya untuk bisa bersanding dengan perempuan yang dicintainya dapat terwujudkan. Dengan merantau seseorang laki-laki berharap agar ia bisa mengumpulkan uang dan bisa mencukupi segala hal yang diperlukan bahkan dapat meminang kekasihnya. Pantang bagi seorang laki-laki jikalau mereka hanya mengandalkan uang dari orang tua.

Mugo gusti ngijabahi aku kowe dadi siji

bakal urip bebrayan, ojo wedi kelangan

aku ning sandingmu, ngancani uripmu

mergo yo mung kowe sing gawe seneng atiku

Usaha seseorang tidak akan pernah terwujud tanpa adanya doa dan meminta kepada sang kuasa. Bahkan sebaliknya, doa yang selalu kita panjatkan tidak akan pernah dikabulkan tanpa adanya usaha. Tidak ada yang mendeskripsikan mana yang lebih didahulukan di antara kedua hal tersebut. Karena kedua hal tersebut sama-sama pentingnya untuk didahulukan. Kedua hal tersebut lebih utama apabila dilakukan secara bersamaan, sehingga menjadi saling melengkapi. Begitulah yang 
dilakukan oleh laki-laki dalam lagu ini. Selain usahanya dengan mengorbankan jauh dari orang-orang yang dicintainya, ia juga tak lupa untuk berdoa dan meminta kepada sang Gusti agar keinginannya untuk menyanding kekasihnya dapat terwujudkan. Sikap yang demikian menggambarkan karakter religius pada diri sang lelaki.

Merga tresna aku bisa Adoh paran njaga rasa

Godaan teka Nanging aku ora ngiwa

Saiki wis urip bareng Susah seneng dilakoni

Ono kowe aku wani Ngadepi urep iki

Telah disinggung sebelumnya, bahwa banyak godaan yang harus dilalui seseorang ketika ia pergi jauh dari pasangan mereka bahkan sampai bertahun-tahun. Godaan untuk mencari pasangan baru selalu tersirat baik dari pihak laki-laki ataupun perempuan. Bahkan sering juga perasangka buruk yang mengatakan bahwa pasangan mereka selingkuh hanya karena pesan SMS atau BBM yang telat dibalas atau pasangan tidak memberikan kabar. Namun bagi seorang laki-laki sejati, ia pasti tidak akan kuat atau mampu jika harus melukai perasaan pasangannya. Sebagai seorang laki-laki ia harus menunjukkan kesetiaannya, karena ketika jauh dari pasangan maka hal tersebut menjadi pembuktian tentang kesetiannya tersebut kepada kekasihnya.

Dalam lirik di atas menceritakan bahwa jarak bukan penghalang untuk menjaga perasaan cinta. Di era modern ini banyak yang dapat dilakukan ketika seorang pasangan jauh dari pandangan mata, salah satunya bisa melalui pesan text, atau video call. Dalam lirik tersebut sang laki-laki menceritakan godaan datang tetapi aku tidak berbelok. Maksud dari lirik tersebut adalah godaan untuk mencari pasangan baru di kota peranturan mungkin sempat terbesit di lubuk hatinya. Namun hal tersebut tidak membuatnya berbelok untuk berpindah ke lain hati karena besar dan tulusnya rasa cinta sang lakilaki pada kekasihnya.

Matur suwun wis gelem nompo aku

Sampun percoyo karo janji janjiku

Bakal takjaga tekaning patiku

Kanggoku awakmu kui harga diriku

Pada dasarnya suatu hubungan harus didasari karena rasa saling percaya dan menguatkan. Bukan hanya janji-jani semata yang hanya bisa diobral, namun bukti sebagai tanda kesetiaan juga harus ditunjukkan untuk menjalin hubungan yang harmonis. Pembuktian rasa 
sayang terhadap kekasihnya tidak dapat dijelaskan secara gamblang. Semua itu tergantung pada kekasih yang menilai sendiri bentuk kesetiaan yang ditampilkan oleh kekasih mereka masing-masing. Ketika seorang laki-laki diberikan kepercayaan, maka ia memiliki kewajiban untuk menjaga kepercayaan tersebut. Salah satu bukti yang dapat dilakukan adalah dengan menjaga baik dari luar maupun dari dalam kekasih atau pasangannya tersebut. Memberikan rasa nyaman, perhatian dan pengertian serta rasa sayang dapat dijadikan sebagai salah satu cara atau bentuk dari rasa terimakasih kepada kekasihnya.

Dalam lirik di atas sang kekasih menuai hasil dari pengorbanan yang telah dilakukannya selama ini. usaha dan pengorbanan yang dilakukannya selama inipun tidak sia-sia. Hal itu terbukti pada lirik lagu tersebut menceritakan bahwa sang lelaki dalam lirik lagu ini akhirnya meminang kekasih yang dicintainya. Lirik lagu tersebut menandakan bahwa hubungan jarak jauh yang selama ini mereka jalani dan mereka hadapipun pada akhirnya dapat dikatakan berhasil. Pengorbanan sang lelalki yang pergi merantau jauh dari orang tua dan orang tercintapun tidak sia-sia.

Adoh ning kene anggonku golek upo

Tak rewangi budal deso

Gen bojo ra ngresulo

Mangan ku tak irit lawuh tempe garit

Senajan awak soyo kuru

Sing penting bojo ra mecucu

Sama halnya dengan lirik lagu Demi Kowe, pada lirik pertama lagu Merantau ini juga menceritakan bentuk pengorbanan seorang suami untuk istrinya. Pada lirik di atas menceritakan seorang suami yang pergi jauh dari kampung halam, demi untuk mencukupi kebutuhan keluarga. Pada lirik gen bojo ra ngresulo, merupakan tujuan utama suami pergi merantau. Seorang laki-laki ketika ia telah memiliki istri istri, maka ia sudah beralih status menjadi kepala keluarga dan kewajiban utama baginya adalah memberikan nafkah baik lahir maupun batin kepada istri dan anak-anaknya. Maka wajar saja apabila seorang wanita atau istri selalu mengeluh jika seorang suami tidak mampu menafkahinya. Uang adalah jalan untuk hidup. Tanpa adanya uang, bagaimana manusia bisa menjalankan hidup? Mau dikasih makan apa anak dan istrinya? Kemarahan seorang wanita apabila lebih memuncak lagi apabila seorang suami penganguran di rumah dan tidak memiliki 
pekerjaan apapun. Kepergian seorang suami untuk merantau merupakan solusi yang dipilih agar bisa menafkahi keluarga.

Pengorbanan suami tak cukup hanya pergi merantau jauh dari kampung halaman. Dalam lirik di atas juga digambarkan bentuk pengorbanan suami ketika ia makan, lauk yang dimakan hanya tempe garit. Tempe garit merupakan salah satu makanan sederhana, murah dan mudah dijangkau. Lauk tempe garit dalam lirik tersebut merupakan bentuk pengorbanan yang dilakukan suami demi membahagiakan istrinya. Meskipun lauk tempe garit jika dirasakan tidak mengenyangkan perut, namun demi membahagiakan istrinya, agar bojo ra mесиси suami rela memakannya. Terkadang, demi mewujudkan keinginan yang diharapkan seseorang perlu adanya pengorbanan. Tempe garit yang dipilih sebagai makanan keseharian suami ketika diperantauan dipilih karena harganya yang murah, sehingga sisa uang yang ia dapatkan bisa dikumpulkan dan nantinya dapat digunakan untuk membahagiaan istrinya di rumah.

Sawise aku mengko sugih

Entenono aku mesti muleh

Tresna ku ra tak tinggalke

Senajan perawan kuto seger nyawange

Semua orang berharap bahwa dengan merantau mereka dapat memperbaiki taraf kehidupannya. Dalam lirik lagu di atas, sang suami berharap agar kepergiannya ke kota dapat menghasilkan uang yang banyak agar nanti ia bisa pulang dan bertemu dengan istrinya. Membawa uang yang banyak, bisa membahagiakan istrinya merupakan salah satu keinginan sang suami yang paling utama dan menjadi sebab alasan ia pergi merantau. Untuk itu kepergiannya ke kota bertujuan agar ia dapat merealisasikan keinginannya tersebut.

Dalam lirik lagu tersebut juga menceritakan kesetiaan suami pada istrinya. Pembahasan pada lirik lagu Demi Kowe sudah dijelaskan bahwa ketika menjalin hubungan jarak jauh dengan kekasih pasti akan ada godaan. Godaan yang ditampilkan dalam lirik lagu di atas adalah perawan-perawan kota yang sedap dipandang. Kehidupan kota yang sangat bebas, terutama di era modern ini mengakibatkan banyak perempuan-perempuan yang ingin tampil semenarik mungkin demi menarik perhatian laki-laki. Maka hal tersebut dapat dikatakan bahwa perawan kota enak dipandang. Maka, laki-laki mana yang tidak mudah terpesona melihat perawan-perawan cantik ditambah lagi mereka jauh dari istri? Pasti tersbesit rasa untuk selingkuh. Meskipun demikian, sang 
suami tak sedikitpun tergoda oleh kecantikan perawan kota. Ia masih mengingat bahwa ia telah memiliki cinta dari seorang istri di rumah dan tidak akan meninggalkan rasa cinta kasihnya pada istrinya.

\author{
Aku pingin mudik \\ Ndang bali mulih glidik \\ Ojo gawe cidro \\ Aku tetep setyo
}

Jauh dari orang-orang yang tersayang memang berat untuk dijalani. Terutama bagi mereka yang sudah berkeluarga dan meninggalkan istri serta anak di rumah. Keinginan untuk pulang pasti ada, meskipun belum dapat menentukan kapan waktu untuk pulang. Kerinduan yang dirasakan baik bagi laki-laki ataupun perempuan ketika menjalin hubungan jarak jauh pasti ada. Bahkan yang sering kita temui terkadang muncul rasa curiga bahwa pasangan kita jauh di sana bermesraan ataupun berduaan dengan orang lain. Maka dari itu dalam lirik lagu di atas menggambarkan bahwa sang laki-laki meminta kepada istrinya di rumah agar tetap setia, menjaga cinta kasih yang telah diberikan oleh suami, sama halnya dengan kesetiannya kepada istrinya. Sang suami berpesan pada istrinya agar ia tidak membuat patah hati sang suami ataupun membuat kecewa sang suami, karena sang suami tidak mungkin berpindah kelain hati.

\title{
Aku wedi koe lungo ro wong liyo \\ Aku ning kene kerjo rekoso \\ Kuatno ati dipaido tonggo-tonggo \\ Nik aku wes sugih mengko tutuke tak bandem telo
}

Lirik lagu di atas masih mempunyai hubungan dengan lirik lirik lagu sebelumnya. Pada lirik di atas masih menceritakan bahwa dalam menjalani hubungan jarak jauh pasti terdapat rasa curiga. Kecurigaan tersebut timbul karena bisikan dari para tetangga yang sering berbicara tidak sesuai dengan fakta (hoax), gosip. Begitulah yang tercermin dari lirik di atas. Kecurigaan suami timbul, yang dibuktikan dengan rasa takut apabila istrinya pergi dengan laki-laki lain. Apabila kecurigaan tersebut benar-benar terjadi, maka rasa kekecewaan akan tumbuh dari hati sang suammi. Rasa kekecewaan tersebut timbul karena sang lakilaki telah berjuang keras, kerja berat demi membahagiakan istrinya, maka ketika istrinya bermain dengan laki-laki lain pasti rasa kekecewaan itu akan tumbuh. 
Dalam lirik di atas suami juga berpesan agar kuat menghadapi ketidakpercayaan yang disampaikan oleh para tetangga. Melihat realita masyarakat bahwa para tetangga sering membicarakan bahwa laki-laki mana yang kuat menahan nafsu ketika mereka jauh dari istri? Tidak mungkin jika mereka tidak main perempuan, seringkali didengar dan menjadi buah bibir. Sehingga bagi seorang istri yang menjalin hubungan jarak jauh karena ditinggal oleh suaminya merantau, pasti akan memunculkan rasa kecurigaan apabila mereka tidak kuat menghadapinya. Dalam hal ini diperlukan rasa saling mengerti, percaya agar hubungan yang telah dibina dapat berjalan dengan harmonis dan lancar.

\section{Persamaan}

Dari hasil uraian di atas maka dapat disimpulkan bahwa kedua lagu tersebut memiliki kesamaan tema. Selain kesamaan tema yang mendasar, sebagai bentuk persamaan dari kedua karya tersebut, kesamaan yang lain juga terdapat pada nilai karakter yang terdapat pada kedua karya tersebut. Adapun nilai-nilai karakter tersebut dapat dilihat sebagai berikut.

Kerja Keras

Kerja keras dapat dipandang sebagai sikap pantang menyerah dan terus berusaha untuk mengejar segala yang diinginkannya. Kemendiknas (dalam Wibowo, 2013) mendefinisikan kerja keras sebagai sikap sungguh-sungguh dalam menyelesaikan setiap hambatan yang dialaminya, serta mampu menyelesaikannya dengan sebaikbaiknya. Hasil dari karakter kerja keras, akan membawa kesuksessan bagi seseorang. Orang yang kerja keras akan mampu meraih kesuksessan. Begitu juga yang tergambar dalam wacana lirik lagu Demi Kowe dan lirik lagu Merantau. Dalam kedua lagu ini karakter kerja keras digambarkan dengan sikap seorang laki-laki yang rela pergi merantau, jauh dari orang-orang tersayang demi untuk mengumpulkan uang agar bisa mewujudkan keinginannya. Hal tersebut dapat dilihat dalam kutipan berikut ini.

Uwes seprene suwene aku lunga ninggal kowe

Adoh paran yo mung dinggo kowe

Aku lilo adoh omah, adoh
Adoh ning kene anggonku golek upo

Tak rewangi budal deso

Gen bojo ra ngresulo

Mangan ku tak irit lawuh 


wong tuwo
Demi Kowe ben supaya
tetep mulya

wong tuwo

tetep mulya tempe garit

Senajan awak soyo kuru

Sing penting bojo ra mecucu

Perjuangan sang laki-laki yang tergambar dalam wacana lirik lagu Demi Kowe ini sangat berat. Hal tersebut dapat dilihat dari lirik di atas, yang merupakan bentuk penggambaran kerja keras seorang lakilaki demi membahagiakan kekasihnya. Penggambaran tersebut digambarkan dengan laki-laki yang rela pergi merantau, mencari pekerjaan, jauh dari rumah dan orangtua sekian lamanya, agar keinginanya untuk bisa meminang kekasihnya dapat tercapai. Berkat usaha dan kerja kerasnya tersebut, akhirnya sang lelaki pun berhasil mewujudkan cita-citanya untuk meminang kekasihnya. Hal tersebut sebagai bukti bahwa segala keinginan yang kita harapkan akan berbuah hasil manis selagi kita mau berusaha dengan sungguh-sungguh. Begitu juga yang tergambar dalam lirik lagu Merantau. Perjuangan seorang suami pergi merantau untun mengumpulkan uang, hingga makanpun harus seadanya dengan harapan agar bisa mendapatkan penghasilan yang layak dan mampu membahgiakan istri di rumah juga merupakan suatu bentuk kerja keras.

Dispilin

Disiplin merupakan sikap taat terhadap peraturan dan ketentuan yang terdapat pada diri seseorang (Kemendiknas dalam Wibowo, 2013). Seseorang yang taat pada peraturan dan ketentuan, baik yang sudah berlaku di masyarakat maka orang tersebut dapat dikatakan sebagai orang yang disiplin. Dalam lirik lagu Demi Kowe maupun lirik lagu Merantau, perilaku disiplin digambarkan dengan perilaku sang lelaki yang tetap setia kepada kekasih atau istrinya, meskipun mendapat godaan berat ketika di perantauan. Kedua lagu ini menceritakan bahwa ketika diperantauan harapan untuk mendua atau mencari pasangan baru pasti ada. Namun karena rasa cintanya yang terlalu besar kepada kekasih atau istrinya, mampu mengantarkan sang laki-laki menajdi pribadi yang disiplin dengan tidak mendua dengan perempuan lain.

Merga tresna aku bisa Adoh paran njaga rasa

Godaan teka Nanging aku ora ngiwa
Tresna ku ra tak tinggalke Senajan perawan kuto seger nyawange 
Kedua lirik yang terdapat dalam lirik lagu Demi Kowe dan Merantau di atas merupakan bentuk dispilin pada diri seorang laki-laki. Karakter disiplin dalam kedua lirik di atas ditunjukkan oleh laki-laki dengan tidak bermain perempuan lain. Dalam menjalani sebuah hubungan, pasangan sebisa mungkin menjauhi apa yang disebut sebagai selingkuh. Jika hal tersebut sampai terjadi, maka hal tersebut tentunya menunjukkan ketidakkonsisten dalam menjalani sebuah hubungan dan dapat merusak hubungan. Pasalnya, dalam menjalani sebuah hubungan maka sepasang kekasih harus saling menyanyangi dan mengasihi, bukan saling menyakiti. Kesetiaan laki-laki yang ditunjukkan dengan tidak tergoda oleh perempuan-perempuan di tanah rantau tersebut sebagai bukti kedisiplinan pada diri laki-laki dalam lirik lagu tersebut.

\section{Mandiri}

Mandiri merupakan karakter yang tidak mudah bergantung pada orang lain. Namun bukan berarti bahwa karakter mandiri tidak berjiwa social sehingga tidak membutuhkan bantuan orang lain. Karakter mandiri merupakan karakter yang tidak bergantung penuh pada orang lain, dalam menyelsaikan segala persoalan yang ia hadapi (Kemendiknas dalam Wibowo, 2013). Artinya di sini adalah krakter mandiri juga membutuhkan bantuan orang lain, namun tidak semuanya bergantung pada orang tersebut sehingga melupakan bahwa dirinya masih memiliki potensi untuk mampu menyelesaikan persoalan yang dihadapinya. Karakter mandiri dalam wacana lirik lagu Demi Kowe dapat dilihat dalam kalimat berikut ini.

\begin{tabular}{l|l}
$\begin{array}{l}\text { Mikir masa depan karo golek } \\
\text { modal }\end{array}$ & $\begin{array}{l}\text { Adoh ning kene anggonku } \\
\text { golek upo } \\
\text { Tingo sesuk } \\
\text { pelaminan }\end{array}$
\end{tabular}

Laki-laki diciptakan memiliki kemampuan yang berbeda dengan perempuan. salah satunya yaitu dari segi kekuatan fisik. kemampuan yang dimilikinya tersebut harus dimanfaatkan untuk dapat memenuhi tanggung jawabnya. Salah satu tanggung jawabnya yang besar pada keluarga yaitu untuk memenuhi kebutuhan ataupun mencukupi nafkah bagi istri dan anak. Dalam wacana lirik lagu Demi Kowe, karakter kemandirian digambarkan dengan sang laki-laki yang berjuang sendirian mencari rezeki dan modal agar bisa menikah dengan kekasihnya. Sehingga sikap mandiri dalam hal ini sang laki-laki tidak bergantung penuh pada orangtuanya demi untuk mewujudkan keinginannya untuk menikahi kekasihnya. Ia berusaha mencari uang 
sendiri untuk bisa mewujudkannya. Pada lirik lagu Merantau, karakter mandiri ditunjukkan oleh sikap seorang suami yang tidak bergantung hidup pada kedua orangtua, dalam membina keluarga. Kepergian suami ke tanah rantau dengan harapan dapat mengumpulkan uang yang nantinya akan ia gunakan untuk membahagiakan anak istrinya merupakan suatu siakp kemadirian. Pasangan suami istri, seharusnya tidak berhak untuk hidup dan terus bergantung pada orangtua. Mereka harus bisa hidup mandiri dan mulai menata masa depan, salah satunya yaitu dengan bekerja dan mengumpulkan penghasilan sendiri untuk menckupui kebutuhan.

Tanggung Jawab

Tanggung jawab merupakan suatu sikap yang mampu mempertanggungjawabkan apa yang telah dilakukanannya serta mampu menanggung resiko terhadap perbuatannya sendiri. Kemendiknas (dalam Wibowo, 2013) mengatakan bahwa tanggung jawab merupakan bentuk perilaku seseorang untuk melaksanakan segala kewajiban yang seharusnya dilakukannya, baik terhadap diri sendiri, lingkngan, masyarakat maupun terhadap Negara. Karakter tanggung jawab dalam wacana lirik lagu Demi Kowe tercermin dari tekad sang laki-laki yang akan menjaga cinta dan kepercayaan yang diberikan oleh kekasihnya. Sedangkan pada lirik lagu Merantau tanggung jawab ditunjukkan oleh sikap suami yang bekerja di tanah rantau untuk membahagiakan istri dan mencukupi kebutuhan istri. Hal itu dapat dilihat dalam kutipan berikut ini.

Bakal tak jaga tekaning
patiku

Kanggoku awakmu kui harga harga diriku
Aku wedi koe lungo ro wong liyo

Aku ning kene kerjo rekoso

Lirik di atas merupakan bentuk tanggung jawab yang seharusnya ada pada setiap diri laki-laki manapun. Jika seorang perempuan telah memberikan kepercayaan kepada seorang laki-laki, maka sang laki-laki harus menjaga kepercayaan tersebut, bukan justru menyia-nyiakannya. Begitulah yang tercemin dari wacana lirik lagu Demi Kowe. Sebagai bentuk tanggung jawab atas kepercayaan yang diberikan oleh kekasihnya, sang laki-laki berjanji akan menjaga kesetiaan tersebut sampai mati. Dimata sang lelaki, kekasihnya tersebut adalah harga dirinya, sehingga ia akan menjaga dengan penuh tanggung jawab 
kekasihnya tersebut. Pada lirik lagu Merantau bentuk tanggung jawab ditunjukkan oleh sang suami yang bekerja dengan berat dan sungguhsungguh demi mewujudkan keinginannya agar bisa mebahagiakan sekaligus memberikan nafkah bagi istrinya. Hal ini merupakan kewajiban seorang suami bahwa ia harus membahagiakan istri, bukan membuat istri selalu bersedih setiap harinya. Membahagiakan istri merupakan suatu kewajiban bagi seorang suami, agar terciptanya keharmonisan dalam rumah tangga.

\section{Perbedaan}

\section{Cerita lagu}

Dari segi cerita lagu tersebut sehingga terlihat bahwa dalam lirik lagu Demi Kowe menceritakan seorang laki-laki yang menepati janjinya untuk menikahi kekasihnya. Hal ini dapat dilihat pada bait pertama yang menceritakan bahwa kepulangan sang laki-laki di sini ingin menepati janjinya untuk menikahi kekasihnya tersebut. Dari bait tersebut mengantarkan pemahaman kepada pendengar bahwa lagu ini berkisah tentang seorang laki-laki yang menepati janji setelah pergi merantau mengumpulkan uang. Hal ini sebagai pembeda dengan lagu Merantau karya Abah Lala, yang lebih menceritakan tentang perjuangan seorang suami untuk membahagiakan istrinya. Lirik lagu Merantau lebih menceritakan beratnya perjuangan yang dialami oleh sang suami ketika di tanah rantau.

\section{Kecurigaan}

Lirik lagu Merantau karya Abah Lala ini juga menceritakan tentang kecurigaan seorang suami pada istri. Suami mana yang tidak curiga ketika istrinya ditinggalkan sendirian di rumah? Hal tersebut lah yang mungkin dirasakan oleh penyair dalam lirik lagu Merantau. Sang suami merasa curiga terhadap istrinya, takut jika nanti istrinya akan mendua ataupun bermesraan dengan laki-laki lain. Sang suami tidak ingin jika perjuangannya yang begitu berat dan penuh dengan pengorbanan di tanah rantau ini akan berakhir pahit karena kelakuan istrinya yang tidak setia. Hal demikian tidak ditemukan dalam lirik lagu Demi Kowe. Sehingga kecurigaan suami kepada istrinya tersebut dapat dijadikan sebagai pembeda antara lirik lagu Demi Kowe dengan lirik lagu Merantau. Pada lirik lagu Demi Kowe, sang laki-laki sangat percaya bahwa rasa cinta yang dimilikinya sama dengan rasa cinta yang dimiliki 
oleh kekasihnya, sehingga tidak ada rasa curiga dalam menjalani hubungan.

\section{Menepati janji}

Meskipun kedua lagu ini menceritakan tentang perjuangan seorang lakilaki yang pergi merantau demi mewujudkan keinginannya untuk membahagiakan kekasih atau istrinya, namun dari segi cerita kedua lagu ini memiliki perbedaan. Pada lagu Demi Kowe menceritakan tentang seorang laki-laki yang datang menemui kekasihnya dan akan menepati janji untuk menikahinya. Pada lagu Merantau menceritakan tentang seorang suami yang pergi merantau untuk membahagiakan istrinya. Sehingga jelas pada kedua lagu ini perbedaan dari segi isi terletak pada status. Status yang baru menjalin hubungan pacaran dengan status suami istri, dan kesetiaan laki-laki dalam menepati janjinya menjadi pembeda dalam pembawaan cerita di lirik lagu Demi Kowe maupun pada lirik lagu Merantau.

\section{Emosi}

Fenomena yang berkembang di masyarakat ketika seorang istri ditinggal pergi oleh suaminya adalah tetangga sering membuat kabarkabar yang tak sedap. Sering sekali mereka membuat kabar bahwa suami mereka pasti mendua atau selingkuh dan mencari perempuan lain. Meskipun berulang kali istri mengelak namun seolah para tetangga tidak peduli dan terus memperkeruh suasana. Hal tersebut seolah tercermin dalam lirik lagu Merantau. Maka dalam lirik lagu Merantau, sang suami berpesan pada istrinya agar ia sabar dan tabah dalam menghadapi mulut tetangga. Ketika suami sudah kaya dan bergelimang harta, pasti ia akan membalas semua perlakuan tetangga yang pernah meremehkannya. Hal yang demikian tidak ditemukan dalam lirik lagu Demi Kowe, sehingga dapat dijadikan sebagai pembeda antara lagu Merantau dengan lagu Demi Kowe.

Religius

Berbeda dengan lirik lagu Merantau, pada lirik lirik lgu Demi Kowe ini ditemukan adanya nilai religius. Hal ini menjadikan pembeda antara lagu Demi Kowe dengan lagu Merantau. Dalam wacana lirik lagu Demi Kowe ini nilai religius digambarkan dengan sang lelaki yang memohon dan berdoa kepada Gusti atau Tuhan agar mengabulkan doanya untuk bisa bersanding di pelaminan dengan kekasihnya. Berdoa kepada tuhan merupakan salah satu ajaran dalam agama. Sebab, selain berusaha, 
dalam meraih keinginannya seseorang juga harus diselingi dengan berdoa dan memohon agar keinginannya tersebut dapat tercapai. Kepergian lelaki untuk merantau ke luar kota merupakan bentuk usaha yang dilakukannya agar bisa mengumpulkan uang untuk modal nikah. Sedangkan doa yang dipanjatkan oleh lelaki dalam lagu ini merupakan bentuk meminta bantuan kepada sang pencipta agar keinginannya dapat dikabulkan. Sehingga kedua hal yang dilakukan oleh sang lelaki tersebut telah sesuai dengan ketentuan bahwa selain berusaha seseorang juga harus diselingi dengan doa agar keinginannya dapat terwujud.

\section{PENUTUP}

Dari hasil analisis di atas dapat disimpulkan bahwa lagu Demi Kowe karya Pendhoza dan lagu Merantau karya Abah Lala memiliki beberapa kemiripan dan beberapa perbedaan. Kemiripan yang paling terlihat dan yang paling mencolok dalam kedua lagu ini adalah dari segi tema lagu. Kedua lagu ini bertemakan perjuangan laki-laki yang pergi Merantau dengan harapan dapat mengumpulkan uang untuk bisa mewujudkan keinginannya membahagiakan kekasih atau istri yang dicintainya. Dari segi nilai karakter yang terkandung dalam kedua lirik inipun juga memiliki kesamaan yaitu kerja keras, disiplin, mandiri dan tanggug jawab. Dari nilai-nilai karakter tersebut diiharapkan dapat diteladani pendengar, terutama bagi seorang laki-laki yang nantinya ia akan menjadi kepala keluarga, tulang punggung keluarga. Meskipun kedua lagu ini memiliki persamaan baik dari segi teman ataupun dari segi nilai-nilai yang dimunculkan, namun kedua lagu ini tentunya juga memiliki perbedaan.

Perbedaannya, lirik lagu Demi Kowe menceritakan tentang seorang laki-laki yang menepati janji setelah pulang dari perantauan untuk menikahi kekasihnya, sedangkan pada lirik Merantau menceritakan perjuangan keras seorang suami pergi merantau untuk membahagiakan istrinya. Berbeda dengan lirik lagu Demi Kowe, pada lirik lagu Merantau menceritakan tentang kecurigaan seorang suami yang ditinggal pergi orang istrinya sekaligus perasaan marah sang suami terhadap omongan tetangga yang kurang enak didengarnya. Dalam lirik lagu Demi Kowe, tidak ditemukannya kedua hal tersebut, namun dalam lirik lagu Demi Kowe ditemukan nilai religius yang menjadi pembeda dengan lagu Merantau. Berdasarkan perbandingan tersebut maka dapat disimpulkan bahwa kedua lirik lagu ini memiliki makna yang sama tentang perjuangan seorang laki-laki yang pergi merantau demi mewujudkan keinginan mereka, namun juga memiliki perbedaan dari segi isi alur lagu sesuai yang sudah dijabarkan di atas. 


\section{DAFTAR PUSTAKA}

Damono, S. J. (2005). Pegangan Penelitian Sastra Bandingan. Jakarta: Pusat Bahasa Departemen Pendidikan Nasional.

Inderasari, E., \& Achsani, F. (2018). Gaya Bahasa Repetisi dan Perbandingan Serta Pesan Moral pada Lirik Lagu Genre Dangdut Koplo. Jurnal Gramatika, 4(2), 325-339.

Kholis, N. (2018). Syiar Melalui Syair: Eksistensi Kesenian Tradisional Sebagai Media Dakwah Di Era Budaya Populer. Al-Balagh, 3(1).

Maghfiroh, N. V. (2018). Citra Perempuan Jawa dalam Novel Canting Karya Arswendo Atmowiloto dan Amba Pendahuluan. Estetik, 1(1), 69-84.

Muhammad. (2014). Metode Penelitian Bahasa. Jogjakarta: Ar-Ruzz Media.

Ni'mah, E. (2017). Pandangan Nasionalisme dalam Puisi Mạ̣mūd Darwisy Dan Rendra dalam Analisis Sastra Banding. An-Nas : Jurnal Humaniora, 2(1), 91-102.

Ratna, N. K. (2013a). Stilistika. Yogyakarta: Pustaka Pelajar.

Ratna, N. K. (2013b). Teori, Metode Dan Teknik Penelitian Sastra. Yogyakarta: Pustaka Pelajar.

Rokhmansyah, A. (2014). Studi dan Pengkajian Sastra; Perkenalan Awal Terhadap Ilmu Sastra. Yogyakarta: Graha Ilmu.

Santosa, R. (2017). Metode Penelitian Kualitatif Kebahasaan. Surakarta: UNS press.

Sugihastuti. (2011). Teori Apresiasi Sastra. Yogyakarta: Pustaka Pelajar Offset.

Waluyo, H. J. (2011). Pengkajian dan Apresiasi Prosa Fiksi. Surakarta: UNS press.

Wibowo, A. (2013). Manajemen Pendidikan Karakter Di Sekolah. Yogyakarta: Pustaka Pelajar. 